\title{
Review \\ The Impact of Selenium Supplementation on Trauma Patients-Systematic Review and Meta-Analysis
}

\author{
Jen-Fu Huang, Chih-Po Hsu, Chun-Hsiang Ouyang, Chi-Tung Cheng $\mathbb{D}$, Chia-Cheng Wang, Chien-Hung Liao *, \\ Yu-Tung $\mathrm{Wu}^{*}$ and Chi-Hsun Hsieh
}

check for

updates

Citation: Huang, J.-F.; Hsu, C.-P.;

Ouyang, C.-H.; Cheng, C.-T.; Wang,

C.-C.; Liao, C.-H.; Wu, Y.-T.; Hsieh,

C.-H. The Impact of Selenium

Supplementation on Trauma

Patients-Systematic Review and

Meta-Analysis. Nutrients 2022, 14,

342. https://doi.org/10.3390/

nu14020342

Academic Editor: Joanna Suliburska

Received: 17 December 2021

Accepted: 12 January 2022

Published: 14 January 2022

Publisher's Note: MDPI stays neutral with regard to jurisdictional claims in published maps and institutional affiliations.

Copyright: (C) 2022 by the authors. Licensee MDPI, Basel, Switzerland. This article is an open access article distributed under the terms and conditions of the Creative Commons Attribution (CC BY) license (https:/ / creativecommons.org/licenses/by/ $4.0 /)$.

\author{
Division of Trauma and Emergency Surgery, Chang Gung Memorial Hospital, Chang Gung University, \\ Taoyuan 33328, Taiwan; jenfuhaung@gmail.com (J.-F.H.); chihpo1227@gmail.com (C.-P.H.); \\ detv090@gmail.com (C.-H.O.); atong89130@gmail.com (C.-T.C.); m0827@cgmh.org.tw (C.-C.W.); \\ hsieh0818@cgmh.org.tw (C.-H.H.) \\ * Correspondence: surgymet@gmail.com (C.-H.L.); overwinterwu@gmail.com (Y.-T.W.); \\ Tel.: +886-3281200 (ext. 3651) (C.-H.L. \& Y.-T.W.)
}

\begin{abstract}
This study aimed to assess current evidence regarding the effect of selenium (Se) supplementation on the prognosis in patients sustaining trauma. MEDLINE, Embase, and Web of Science databases were searched with the following terms: "trace element", "selenium", "copper", "zinc", "injury", and "trauma". Seven studies were included in the meta-analysis. The pooled results showed that Se supplementation was associated with a lower mortality rate (OR 0.733, 95\% CI: 0.586, 0.918, $p=0.007$; heterogeneity, $I^{2}=0 \%$ ). Regarding the incidence of infectious complications, there was no statistically significant benefit after analyzing the four studies (OR 0.942, 95\% CI: 0.695, 1.277, $p=0.702$; heterogeneity, $I^{2}=14.343 \%$ ). The patients with Se supplementation had a reduced ICU length of stay (standard difference in means (SMD): $-0.324,95 \%$ CI: $-0.382,-0.265, p<0.001$; heterogeneity, $I^{2}=0 \%$ ) and lesser hospital length of stay (SMD: $-0.243,95 \%$ CI: $-0.474,-0.012$, $p<0.001$; heterogeneity, $I^{2}=45.496 \%$ ). Se supplementation after trauma confers positive effects in decreasing the mortality and length of ICU and hospital stay.
\end{abstract}

Keywords: trace element; selenium; trauma; injury

\section{Introduction}

Traumatic injury accounts for the major causes of death worldwide, and the trimodal of trauma mortality is well established [1]. The first and second peaks were difficult to overcome due to the trauma event itself [2]. However, the third peak in the trimodal model, which is late deaths that occur days to weeks after injury, has become less prominent with the progress of medicine [3]. In this phase, multiorgan failure resulting from infection and sepsis has become one of the major causes of mortality [4-6]. Moreover, patient condition is impacted by an initial cascade of inflammation and then aggravated by sepsis [5]. Importantly, advancements in sepsis treatment and critical care strategies have led to the reduction in late mortality [7].

Significant inflammatory responses and severe metabolic disturbances have been noted after major trauma [8]. Selenium (Se) is a key player in regulating immunity and inflammation responses and an essential micronutrient required for more than 25 proteins in the body [9]. These proteins have many functions, including antioxidant defense, protein folding [9], thyroid hormone metabolism [10], and immune health. Moreover, Se has proven to be beneficial in the prevention and recovery of many diseases, such as autoimmune thyroiditis, cancer, and heart disease [11,12]. Reduced Se intake is associated with poor health across the lifespan, increasing Se requirements during pregnancy and lactation and in older individuals [13]. A lack of trace elements could result in sepsis, delayed wound healing, and muscle catabolism. The role of trace elements in major trauma and subsequent sepsis remains unclear. 
A lower Se level was found rapidly after trauma events [14,15]. Se plays a critical physiological role in immune function, wound healing, and protein folding and elicits antioxidative effects, which are rapidly depleted after trauma insults $[16,17]$. Se deficiencies are assumed to result from hemorrhage and massive fluid installation [18,19]. Selenium deficiency has been known to negatively affect immune cells during activation, differentiation, and proliferation [12]. Furthermore, low serum Se levels, with increased oxidative stress and inflammatory biomarkers, are frequently found in critically ill patients and are associated with poor prognosis [20]. Therefore, trauma patients with low serum Se levels may develop more infectious complications and, thus, bear a higher risk of adverse outcomes.

Nutrition support guidelines are available and provide suggestions for intensive care unit (ICU) settings [21]. These guidelines are adopted for patients with major trauma. However, the critical care population is heterogeneous, and guidelines might not apply to trauma patients. Patients who have sustained major trauma might have a unique demand for nutritional support; therefore, evidence-based recommendations for nutritional therapy in major trauma should be more specific. Recent nutritional therapy recommendations have suggested micronutrient substitution, including Se for patients with major burns [19]. To our knowledge, there are no critical and thorough analyses to support the efficacy of Se supplementation in severe trauma patients.

The objective of this review is to assess current evidence regarding the effectiveness of Se supplementation on mortality, length of ICU/hospital stay, and infection rates in patients having sustained trauma.

\section{Materials and Methods}

\subsection{Protocol and Registration}

A systematic literature search was performed based on the 2019 Preferred Reporting Items for Systematic Reviews and Meta-analyses (PRISMA) statement. This study was registered in Prospero (registered no. 297041).

\subsection{Eligibility Criteria}

Population.

This review considered studies that included acute trauma patients who had been admitted to hospital and received Se supplementation during hospitalization.

Intervention and Comparison.

Studies that evaluated nutrition support with Se, compared with placebo or standard treatment, were enrolled.

Outcome Measures.

Primary outcome measures for this review were mortality, length of stay (LOS; ICU/hospital), and complications (e.g., nosocomial infection, hospital-acquired pneumonia).

Studies.

This review considered randomized controlled trials (RCTs), experimental and epidemiological study designs (including non-randomized controlled trials, before and after studies), and prospective and retrospective cohort studies.

\subsection{Information Sources and Search}

We searched the MEDLINE, Embase, and Web of Science electronic databases. We confined the search to the English language and selected publication dates between January 1990 and December 2020. The following subject headings: "trace element", "selenium", "copper", "zinc", "injury", and "trauma" were used. Table 1 provides these details. Moreover, the references of relevant articles were evaluated for other eligible studies. 
Table 1. Search strategy including keywords and filters/limits.

\begin{tabular}{|c|c|c|}
\hline Database & Search Terms & Filters/Limits \\
\hline PubMed & $\begin{array}{l}\text { (trace element OR selenium OR copper } \\
\text { OR zinc) AND (trauma OR injury) }\end{array}$ & $\begin{array}{l}\text { Clinical Trial, Randomized } \\
\text { Controlled Trial, Humans, } \\
\text { English, 1990-2021 }\end{array}$ \\
\hline Embase & $\begin{array}{l}\text { (trace:ti,ab AND element:ti,ab OR } \\
\text { selenium:ti,ab OR zinc:ti,ab OR } \\
\text { copper:ti,ab) AND (trauma:ti,ab OR } \\
\text { injury:ti,ab) }\end{array}$ & $\begin{array}{l}\text { (humans)/lim AND } \\
\text { (English)/lim AND (clinical } \\
\text { study)/lim AND } \\
(1990-2021) / \text { py }\end{array}$ \\
\hline Web of Science & $\begin{array}{l}((\mathrm{TS}=(\text { trace element OR selenium OR } \\
\text { copper OR zinc) }) \text { OR }(\mathrm{TI}=(\text { trace } \\
\text { element OR selenium OR copper OR } \\
\text { zinc }))) \text { AND }((\mathrm{TS}=(\text { trauma OR injury })) \\
\text { OR TI = (trauma OR injury) }) \text { NOT ALL } \\
=(\text { in vitro OR rabbit OR rat OR animal } \\
\text { OR mice OR mouse OR pig OR porcine } \\
\text { OR sheep OR lamb) AND } \\
(\mathrm{DT}=(\text { "ARTICLE" OR “MEETING } \\
\text { ABSTRACT" OR “PROCEEDINGS } \\
\text { PAPER" OR “EDITORIAL MATERIAL" } \\
\text { OR “EARLY ACCESS")) }\end{array}$ & 1990-2021 \\
\hline
\end{tabular}

\subsection{Study Selection}

The titles and abstracts were screened by two independent reviewers (J. F. Huang and C. P. Hsu) to determine the suitability of the studies for inclusion. Only studies that could provide data were used, since this allowed for calculating the odds ratio and relative risk factors. Furthermore, case reports and editorials were excluded.

\subsection{Data Collection Process and Quality Assessment}

Two reviewers (J. F. Huang and C. P. Hsu) independently extracted the data. Data included details about the interventions (dosage, route, duration, and regimen), demographics (age, gender), study methods (study design, case numbers), and outcomes (ICU length of stay (LOS), hospital LOS, morbidity, and mortality). When encountering missing data, these data were calculated using information from the publications.

The authorship or institution was not blinded to the reviewers. Disagreements regarding the entire review process were consulted by a third reviewer (C. H. Liao). The modified Jadad scale was used to assess the quality of the studies.

\subsection{Data Synthesis}

Quantitative data were pooled for the meta-analysis with the Comprehensive MetaAnalysis (CMA) 3.0 software (Biostat, Englewood, NJ, USA). Effect sizes were reported as odds ratios (OR) with 95\% confidence intervals (CI) for mortality and infections. The standard difference in means (SMD) and their 95\% CI for LOS were calculated. Heterogeneity was assessed statistically using the standard $\chi 2$ test and inconsistency quantified by the $I^{2}$ test. Owing to the small number of included studies, publication bias was not tested, due to the insufficient power to detect real asymmetry [22]. A value of $p<0.05$ was regarded as statistically significant.

\section{Results}

\subsection{Study Selection}

Through database searching, we identified 2671 citations. Twenty full-text articles were assessed for eligibility, 13 of which were rationally excluded. The remaining seven studies met the methodological quality criteria and were included in the meta-analysis $[10,23-28]$. The study selection process is illustrated in Figure 1. 


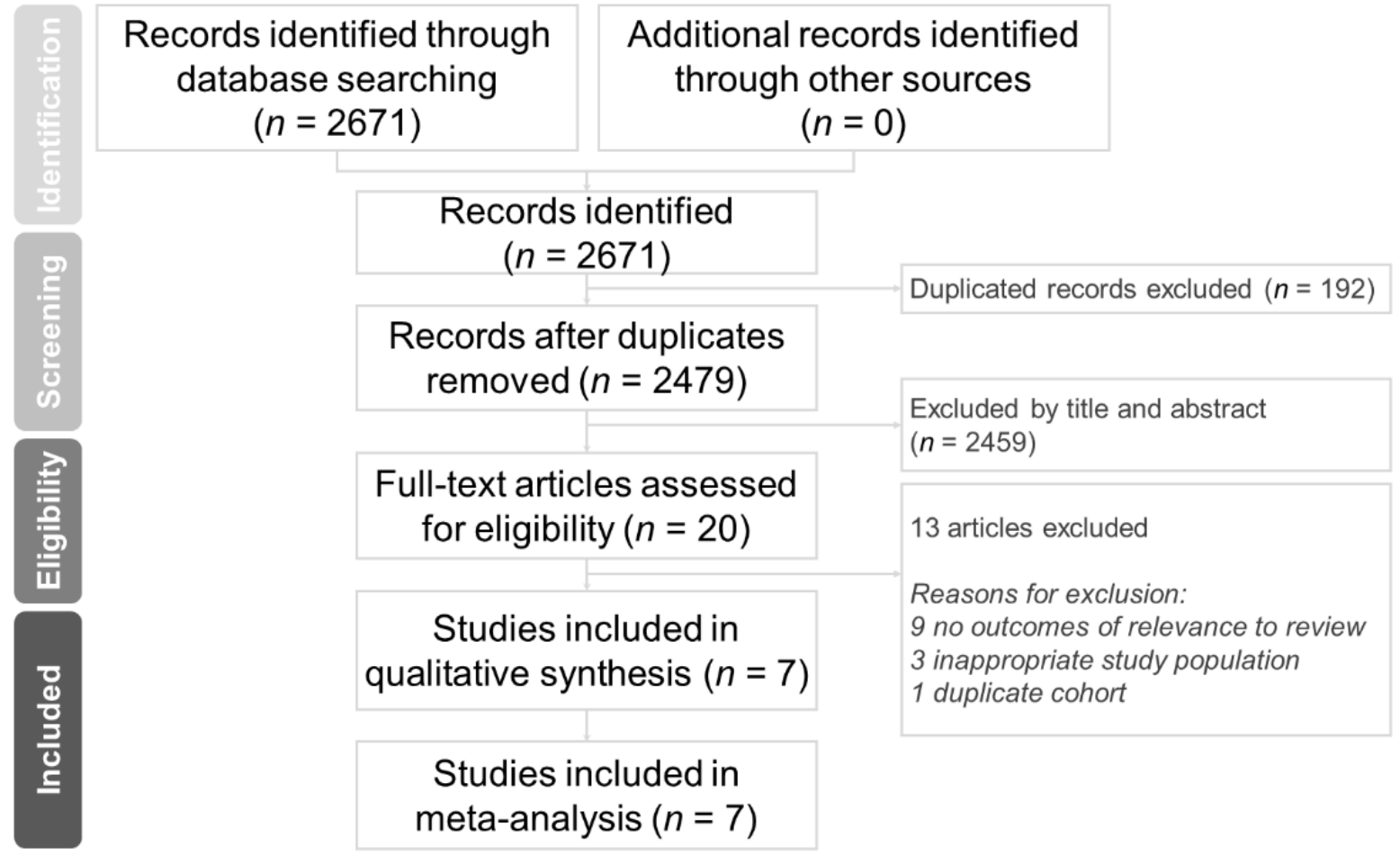

Figure 1. Protocol of this systematic review.

\subsection{Study Characteristics}

The included studies were four prospective, randomized, blinded, control trials $[10,23,24,27]$ and three non-randomized experimental trials $[25,26,28]$. Characteristics of the included studies and the extracted data are disclosed in Table 2. The studies in this review had 4564 participants.

Table 2. Characteristics of included studies.

\begin{tabular}{|c|c|c|c|c|c|}
\hline Study & Methods & Participants, Setting & Intervention & $\begin{array}{l}\text { Outcome } \\
\text { Measures }\end{array}$ & $\begin{array}{l}\text { Modified } \\
\text { Jadad } \\
\text { Scale }\end{array}$ \\
\hline $\begin{array}{l}\text { Porter } \\
\text { et al. } \\
(1999)\end{array}$ & $\begin{array}{l}\text { Study design: } \\
\text { prospective RCT } \\
\text { Duration of } \\
\text { follow-up: } \\
\text { until discharge }\end{array}$ & $\begin{array}{l}\text { Participants: } \\
\text { Total } n=18 \\
\text { Intervention } n=9 \text {; placebo } n=9 \\
18 \text { males } \\
\text { Mean age: } 32.4 \text { years } \\
\text { Setting: } \\
\text { ICU, Lincoln Medical Center, Bronx, } \\
\text { New York } \\
\text { Inclusion criteria: } \\
\text { age } 15-80 \text {; penetrating injury } \\
\text { involving multiple systems, ISS not } \\
<25 \text { or abdominal trauma index not } \\
<25 \text {, or any two of the following: } \\
\text { prehospital and admission SBP }<90 \text {, } \\
\text { initial right atrial venous oxygen } \\
\text { tension of }<35 \text { mm Hg and O } 2 \\
\text { saturation of }<65 \% \text {, base excess } \\
\text { worse than }-8, \text { or serum lactate }>4\end{array}$ & $\begin{array}{l}\text { Intervention: } \\
50 \text { mg of selenium IV, Q6H, } \\
400 \text { IU of vitamin E PO Q8H, } \\
100 \text { mg of vitamin C PO } \\
\text { Q8H, and } 8 \text { g of } \\
\text { N-acetylcysteine (NAC) PO } \\
\text { Q6H for } 7 \text { days, stay in ICU } \\
\text { or until death, whichever } \\
\text { one was shorter } \\
\text { Control: } \\
\text { Standard therapeutic care }\end{array}$ & $\begin{array}{l}\text { Mortality, } \\
\text { incidence of } \\
\text { septic compli- } \\
\text { cations, } \\
\text { ARDS, } \\
\text { MODS, } \\
\text { hospital stays }\end{array}$ & $6.5 / 8$ \\
\hline
\end{tabular}


Table 2. Cont.

\begin{tabular}{|c|c|c|c|c|c|}
\hline Study & Methods & Participants, Setting & Intervention & $\begin{array}{l}\text { Outcome } \\
\text { Measures }\end{array}$ & $\begin{array}{l}\text { Modified } \\
\text { Jadad } \\
\text { Scale }\end{array}$ \\
\hline $\begin{array}{l}\text { Berger } \\
\text { et al. } \\
(2000)\end{array}$ & $\begin{array}{l}\text { Study design: } \\
\text { prospective RCT, } \\
\text { DB } \\
\text { Duration of } \\
\text { follow-up: } \\
\text { until discharge }\end{array}$ & $\begin{array}{l}\text { Participants: } \\
\text { Total } n=31 \\
\text { Intervention } n=20 \text {; placebo } n=11 \\
23 \text { males and } 8 \text { females } \\
\text { Mean age: } 42 \pm 16 \text { years } \\
\text { Setting: } \\
\text { ICU, Centre Hospitalier } \\
\text { Universitaire Vaudois, Lausanne, } \\
\text { Switzerland } \\
\text { Inclusion criteria: } \\
\text { Age } 18-75 \text {; multiple injuries with } \\
\text { ISS }>15 \text {; admission within first } 24 \mathrm{~h} \\
\text { of injury }\end{array}$ & $\begin{array}{l}\text { Intervention: } \\
\text { Selenium } 500 \mu \mathrm{g} \text { IV QD, } \\
\text { with or without vitamin E } \\
150 \mathrm{mg} \text { IV QD, Zn } 13 \mathrm{mg} \text { IV } \\
\text { QD for } 5 \text { days } \\
\text { Control: } \\
\text { placebo }\end{array}$ & $\begin{array}{l}\text { Mortality, } \\
\text { incidence of } \\
\text { complica- } \\
\text { tions and } \\
\text { organ failure, } \\
\text { hospital stays }\end{array}$ & $8 / 8$ \\
\hline $\begin{array}{l}\text { Berger } \\
\text { et al. } \\
(2008)\end{array}$ & $\begin{array}{l}\text { Study design: } \\
\text { prospective RCT, } \\
\text { DB } \\
\text { Duration of } \\
\text { follow-up: } \\
3 \text { months after } \\
\text { discharge }\end{array}$ & $\begin{array}{l}\text { Participants: } \\
\text { Total } n=66 \\
\text { Intervention } n=34 \text {; placebo } n=32 \\
52 \text { males and } 14 \text { females } \\
\text { Mean age: } 40 \pm 19 \text { years } \\
\text { Setting: } \\
\text { ICU, Centre Hospitalier } \\
\text { Universitaire Vaudois, Lausanne, } \\
\text { Switzerland } \\
\text { Inclusion criteria: } \\
\text { ISS }>9\end{array}$ & $\begin{array}{l}\text { Intervention: } \\
\text { selenium } 270 \mu \mathrm{g} I V \text {, zinc } 30 \\
\text { mg IV, vitamin C } 1.1 \mathrm{~g} \mathrm{IV} \text {, } \\
\text { vitamin } \mathrm{B}_{1} 100 \mathrm{mg} \text { IV, } \\
\text { vitamin E } 6.4 \mathrm{mg} \text { IV and } 300 \\
\text { mg PO with a } \\
\text { double-loading dose on } \\
\text { days } 1 \text { and } 2 \text {, total for } 5 \text { days } \\
\text { plus ICU standard vitamin } \\
\text { profile (as for control group) } \\
\text { Control: } \\
\text { ICU standard vitamin } \\
\text { profile: } 500 \text { mg vitamin } \\
\text { C/day for } 5 \text { days and } 100 \\
\text { mg vitamin B1/day for } 3 \\
\text { days }\end{array}$ & $\begin{array}{l}\text { Mortality, } \\
\text { hospital } \\
\text { stays, } \\
\text { kidney } \\
\text { function, } \\
\text { subsequent } \\
\text { organ failure, } \\
\text { infections } \\
\text { and } \\
\text { pneumonia }\end{array}$ & $8 / 8$ \\
\hline $\begin{array}{l}\text { Collier } \\
\text { et al. } \\
(2008) \\
\text { Giladi } \\
\text { et al. } \\
(2011)\end{array}$ & $\begin{array}{l}\text { Study design: } \\
\text { Retrospective } \\
\text { cohort study } \\
\text { Duration of } \\
\text { follow-up: } \\
\text { Until discharge }\end{array}$ & $\begin{array}{l}\text { Participants: } \\
\text { Total } n=4294 \\
\text { Patients after AO protocol, } n=2272 \\
\text { Patients before AO protocol, } \\
n=2022 \\
3284 \text { males and } 1010 \text { females } \\
\text { Mean age: } 40 \text { years } \\
\text { Setting: } \\
\text { Level I Trauma Center, Vanderbilt } \\
\text { University Medical Center } \\
\text { Inclusion criteria: } \\
\text { All admitted trauma patients }\end{array}$ & $\begin{array}{l}\text { AO protocol for all admitted } \\
\text { trauma patients: } \\
\text { selenium } 200 \mu \mathrm{g} \text { IV QD, } \\
\text { vitamin C } 1 \mathrm{~g} \text { IV Q8H, } \\
\text { vitamin E } 1000 \mathrm{IU} \mathrm{PO} \mathrm{Q} 8 \mathrm{H} \\
\text { for } 7 \text { days or until hospital } \\
\text { discharge, whichever was } \\
\text { shorter. } \\
\text { Control: } \\
\text { Patients admitted to the } \\
\text { trauma center one year } \\
\text { before implementation of } \\
\text { AO protocol }\end{array}$ & $\begin{array}{l}\text { Mortality, } \\
\text { hospital } \\
\text { stays, } \\
\text { development } \\
\text { of organ } \\
\text { failure or } \\
\text { dysfunction, } \\
\text { infectious } \\
\text { complica- } \\
\text { tions }\end{array}$ & $2 / 8$ \\
\hline $\begin{array}{l}\text { Soguel } \\
\text { et al. } \\
(2008)\end{array}$ & $\begin{array}{l}\text { Study design: } \\
\text { Prospective } \\
\text { study with } \\
\text { historical control } \\
\text { Duration of } \\
\text { follow-up: } \\
\text { Until discharge }\end{array}$ & $\begin{array}{l}\text { Participants: } \\
\text { Total } n=40 \\
\text { Intervention } n=20 \text {; control } n=20 \\
30 \text { males and } 10 \text { females } \\
\text { Mean age: } 43.5 \pm 19.2 \text { years } \\
\text { Setting: } \\
\text { ICU, Centre Hospitalier } \\
\text { Universitaire Vaudois, Lausanne, } \\
\text { Switzerland } \\
\text { Inclusion criteria: } \\
\text { Trauma patients needed ICU care }\end{array}$ & $\begin{array}{l}\text { Intervention: } \\
\text { selenium } 300 \mu \mathrm{g} \text { PO QD, } \\
\text { zinc } 30 \text { mg PO QD, vitamin } \\
\text { C } 1.5 \text { g PO QD, vitamin E } \\
500 \text { mg PO QD for } 10 \text { days; } \\
\text { vitamin } B_{1} 100 \text { mg IV QD, } \\
\text { vitamin C } 500 \text { mg IV QD for } \\
5 \text { days } \\
\text { Control: } \\
\text { historical matched controls } \\
\text { matching criteria: age, sex, } \\
\text { ISS, brain injury, and SAPS } \\
\text { II score. }\end{array}$ & $\begin{array}{l}\text { Sequential } \\
\text { organ failure } \\
\text { assessment } \\
\text { (SOFA) score, } \\
\text { mortality, } \\
\text { hospital } \\
\text { stays, } \\
\text { infection } \\
\text { complica- } \\
\text { tions }\end{array}$ & $4 / 8$ \\
\hline
\end{tabular}


Table 2. Cont.

\begin{tabular}{|c|c|c|c|c|c|}
\hline Study & Methods & Participants, Setting & Intervention & $\begin{array}{l}\text { Outcome } \\
\text { Measures }\end{array}$ & $\begin{array}{l}\text { Modified } \\
\text { Jadad } \\
\text { Scale }\end{array}$ \\
\hline $\begin{array}{l}\text { van } \\
\text { Zanten } \\
\text { et al. } \\
(2014)\end{array}$ & $\begin{array}{l}\text { Study design: } \\
\text { prospective RCT, } \\
\text { DB } \\
\text { Duration of } \\
\text { follow-up: } \\
6 \text { months after } \\
\text { start of study } \\
\text { product }\end{array}$ & $\begin{array}{l}\text { Participants: } \\
\text { Total } n=109 \\
\text { Intervention } n=55 \text {; control } n=54 \\
87 \text { males and } 22 \text { females } \\
\text { Mean age: } 43 \text { years } \\
\text { Setting: } \\
\text { ICU, multi-country, multi-center } \\
\text { Inclusion criteria: } \\
\text { age } \geq 18 \text { years, mechanically } \\
\text { ventilated ICU patients }\end{array}$ & $\begin{array}{l}\text { Intervention: } \\
\text { Tube feed formula enriched } \\
\text { in glutamine, vitamins C } \\
\text { and E, selenium, zinc, and } \\
\text { EPA and DHA and low in } \\
\text { carbohydrate content } \\
\text { maximum for } 28 \text { days } \\
\text { during ICU stay } \\
\text { Control product: } \\
\text { Isocaloric standard tube } \\
\text { feed with the same amount } \\
\text { of protein. }\end{array}$ & $\begin{array}{l}\text { Incidence of } \\
\text { nosocomial } \\
\text { infections } \\
\text { and organ } \\
\text { failure, } \\
\text { duration of } \\
\text { ventilation, } \\
\text { ICU, and } \\
\text { hospital stay, } \\
\text { mortality }\end{array}$ & $8 / 8$ \\
\hline
\end{tabular}

RCT: randomized control trial; ICU: intensive care unit; ISS: injury severity score; SBP: systolic blood pressure; DB: double blinded; AO: antioxidant; EPA: eicosapentaenoic acid; DHA: docosahexaenoic acid.

\subsection{Analysis}

Six studies reported the impact of Se supplementation on the mortality rate of patients sustaining major trauma $[10,23-25,27,28]$. The pooled results showed that Se supplementation was associated with a lower mortality rate (Figure 2, OR 0.733, 95\% CI: 0.586, 0.918, $p$ $=0.007$; heterogeneity, $I^{2}=0 \%$ ). Regarding the incidence of infectious complications, there was no statistically significant benefit after analyzing the four studies (Figure 3, OR 0.942, 95\% CI: $0.695,1.277, p=0.702$; heterogeneity, $I^{2}=14.343 \%$ ) $[23,24,26,27]$.

\section{Study name}

$\begin{array}{lrrr} & \begin{array}{c}\text { Odds } \\ \text { ratio }\end{array} & \begin{array}{c}\text { Lower } \\ \text { limit }\end{array} & \begin{array}{c}\text { Upper } \\ \text { limit }\end{array} \\ \text { Berger et al. (2001) } & 1.111 & 0.089 & 13.835 \\ \text { Berger et al. (2008) } & 3.214 & 0.598 & 17.266 \\ \text { Collier et al. (2008) } & 0.705 & 0.559 & 0.890 \\ \text { Soguel et al. (2008) } & 0.477 & 0.040 & 5.664 \\ \text { van Zanten et al. (2014) } & 0.980 & 0.295 & 3.251 \\ & 0.733 & 0.586 & 0.918\end{array}$

\section{Odds ratio and $95 \% \mathrm{CI}$}

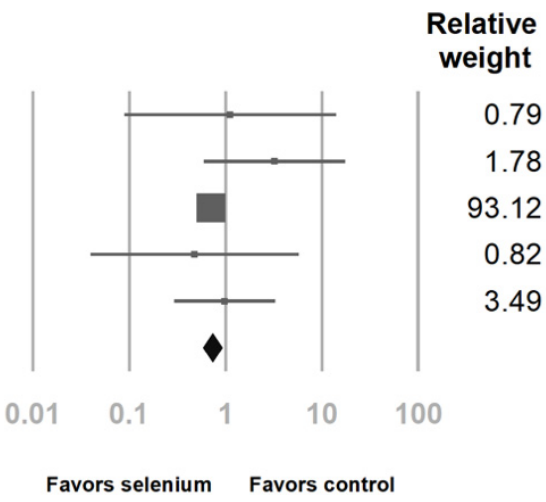

Figure 2. Forest chart of selenium (Se) supplementation on mortality of severe trauma patients. 
Study name

$\begin{array}{lccc} & \begin{array}{c}\text { Odds } \\ \text { ratio }\end{array} & \begin{array}{c}\text { Lower } \\ \text { limit }\end{array} & \begin{array}{c}\text { Uppe } \\ \text { limit }\end{array} \\ \text { Porter et al. (1999) } & 0.156 & 0.013 & 1.82 \\ \text { Berger et al. (2008) } & 1.462 & 0.552 & 3.87 \\ \text { Giladi et al. (2011) } & 0.978 & 0.826 & 1.157 \\ \text { van Zanten et al. (2014) } & 0.696 & 0.319 & 1.51 \\ & 0.942 & 0.695 & 1.27\end{array}$

Odds ratio and $95 \% \mathrm{Cl}$

\section{Relative \\ weight}

1.51

8.88

76.39

13.22

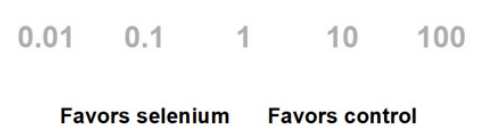

Figure 3. Forest chart of selenium (Se) supplementation on infection occurrence in severe trauma patients.

Six studies disclosed intensive care unit (ICU) and hospital stays [10,23-25,27,28]. The patients with Se supplementation had shorter ICU lengths of stay (Figure 4, standard difference in means (SMD): $-0.324,95 \%$ CI: $-0.382,-0.265, p<0.001$; heterogeneity, $I^{2}=0 \%$ ). The hospital length of stay was also shorter with Se supplementation. (Figure 5, SMD: $-0.243,95 \%$ CI: $-0.474,-0.012, p<0.001$; heterogeneity, $I^{2}=45.496 \%$ ).

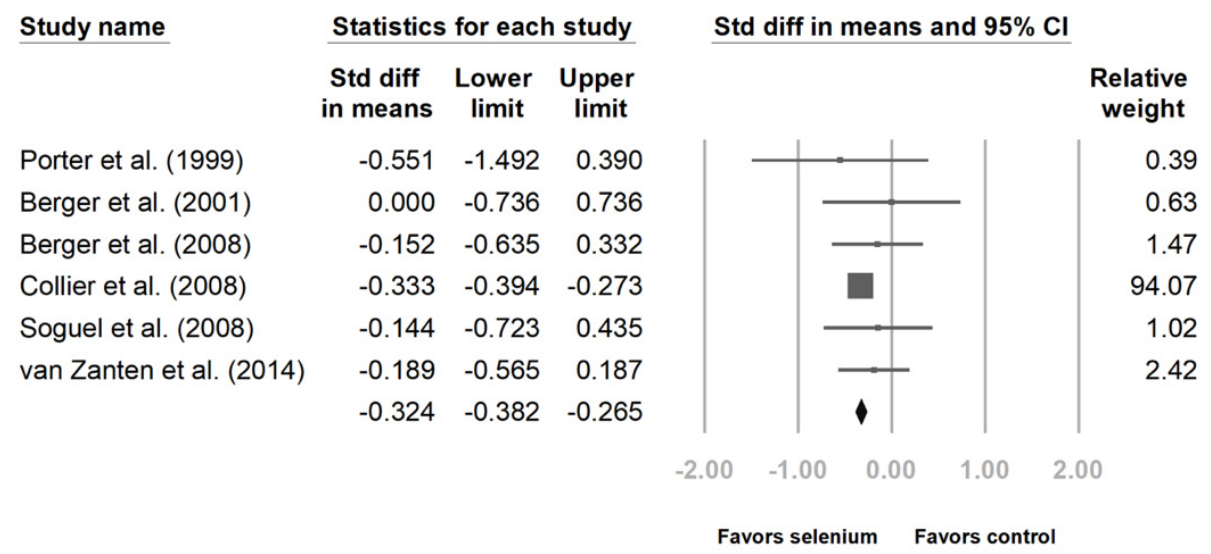

Figure 4. Forest chart of selenium (Se) supplementation on the length of intensive care unit stay of severe trauma patients.

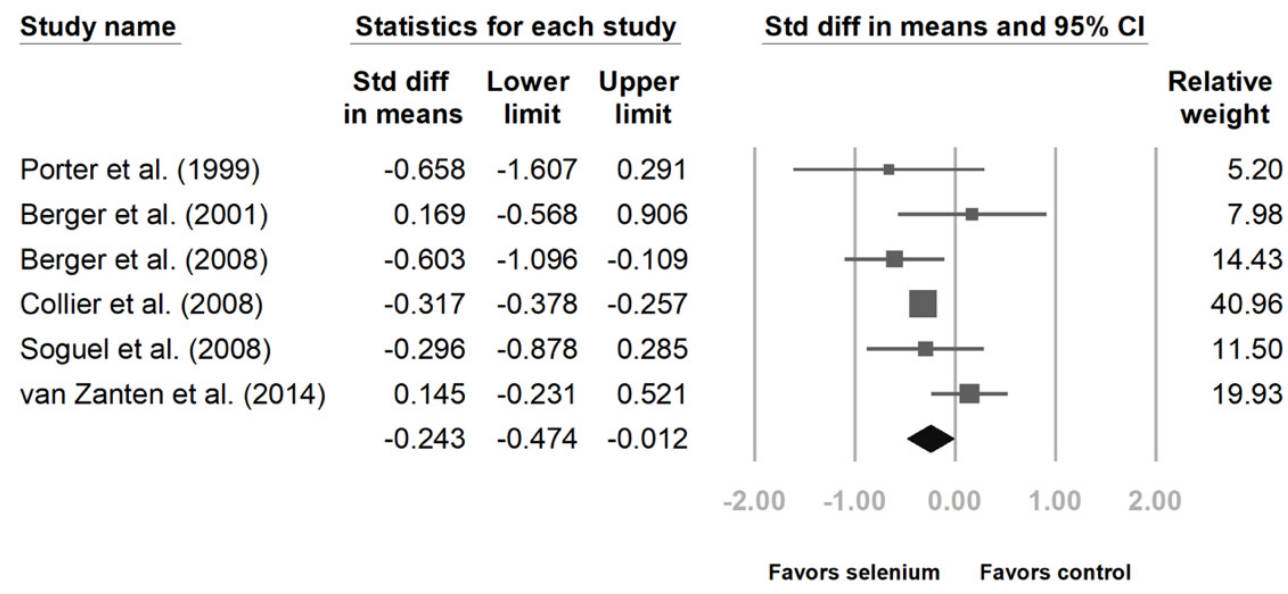

Figure 5. Forest chart of selenium (Se) supplementation on the length of hospital stay of severe trauma patients. 


\section{Discussion}

In this meta-analysis, Se supplementation for severe trauma patients was examined. The current evidence supports that Se administration decreases the mortality rate and ICU and hospital stay for patients who have sustained major trauma. The pooled analysis suggested that Se supplementation was not associated with infectious complications after major trauma.

Deceased mortality was observed in patients administered Se supplementation (OR $0.733,95 \%$ CI: $0.586,0.918, p=0.007)$. As the trimodal of mortality has shown [1], the mortality of trauma patients is initially related to injury severity. The protective effect of Se might reduce the inflammatory responses after severe trauma and, accordingly, reduce the mortality in the recovery phase. There were only limited numbers of studies with relatively small sample sizes, so the effect on mortality should be interpreted with caution. Moreover, the large cohort could influence the result for the study group. The hypermetabolic response, trace element losses following hemorrhage, and fluid resuscitation are unique to trauma. Some studies have reported that supplementary Se did not improve survival in critically ill patients $[29,30]$. In these studies, Se supplementation was provided to random critically ill patients without considering the patients' conditions. In contrast, some authors reported that Se administration could be beneficial for patients with Se deficiency whether in severe burn or multiple trauma $[15,31]$.

In this review, we identified the statistically significant effect of Se on length of hospital or ICU stay. It is reasonable to conclude that Se can reduce the inflammatory process during acute injury and shorten the recovery phase. The cost savings for the decrease in LOS outweigh the cost of the intervention. Further cost and benefit analyses would be worthwhile to assist clinicians and patients to understand the value of nutritional therapy. However, in the current review, the immunomodulation effect of Se did not translate to a reduction in infections. Therefore, the underlying mechanism should be clarified.

There were two studies that provided serum Se levels and addressed the effective dose range. However, the actual effective dose remains uncertain. Brätter et al. reported an estimated safe dose of $500 \mathrm{mcg} /$ day for Se supplementation to avoid inhibition of the hepatic deiodinase. [32] Thus, the two studies used $500 \mathrm{mcg} /$ day and $540 \mathrm{mcg} /$ day as a supplement and found a significant increase in the serum Se level after a five-day intervention. Furthermore, the Se supplementation was associated with incremental thyroid hormone and glutathione peroxidase concentrations. Although not considered direct evidence, based on the available evidence, a daily Se dose of $500 \mathrm{mcg}$ for five days might be suitable for patients who have sustained major trauma. Furthermore, all included studies in this review used a mixture of nutritional supplements rather than Se alone. In addition, the laboratory results also offered a clue regarding the effect of Se in the experimental mixture.

Recent investigations reported that a higher serum Se level was associated with hyperglycemia and type 2 diabetes mellitus (T2DM) [33-36]. Moreover, there were some conflicting studies regarding dietary Se supplementation and the risk of T2DM. Several cohorts disclosed that dietary Se supplements carried a risk of T2DM [35,37]. Nevertheless, some analyses showed a neutral or positive effect of Se supplementation on T2DM [38,39]. Coincidentally, higher serum Se levels were found to be related to dyslipidemia [40,41]. More efforts should be made to clarify the role of Se in metabolic diseases. Moreover, clinicians should bear in mind the metabolic effect of Se and ensure that patients supplemented with Se receive proper monitoring of their metabolic parameters during nutrition therapy.

Limited studies reported the use of Se supplementation in major trauma patients and lacked large-scale clinical trials. Importantly, this review contributed by providing evidence to this field. However, there were limitations in this review. First, when interpreting this review, the small number of studies with small sample sizes introduced possible type II errors. Second, since the included studies spanned 20 years, changes in trauma management over time could be another confounding factor. Third, variations in dosages and the mixture of antioxidants mask the actual effects of Se supplementation. Moreover, only two 
studies provided serum test results, and it was difficult to ensure the clinical benefit of Se supplementation and the underlying mechanism. In the future, large multicenter studies that consider injury severity, Se dosage, metabolic effects, and serum markers are essential to provide definitive evidence.

\section{Conclusions}

This review indicates that Se supplementation after severe trauma confers positive effects in decreasing the overall lengths of ICU and hospital stay. This review also indicates that Se supplementation appears safe and does not increase mortality or other reported adverse side effects.

Author Contributions: Conceptualization, C.-H.L. and Y.-T.W.; methodology, J.-F.H., C.-H.O., and C.-C.W.; software, C.-T.C. and C.-P.H.; validation, C.-H.L. and C.-H.H.; formal analysis, J.-F.H. and C.-P.H.; writing-original draft preparation, J.-F.H. and C.-P.H.; writing-review and editing, Y.-T.W. and C.-H.L.; visualization, J.-F.H.; supervision, C.-H.H.; funding acquisition, Y.-T.W. All authors have read and agreed to the published version of the manuscript.

Funding: This research was funded by Chang Gung Memorial Hospital Research Grant, grant number: CMRPG3K1631 and CMRPG3J1121.

Institutional Review Board Statement: Not applicable.

Informed Consent Statement: Not applicable.

Conflicts of Interest: The authors declare no conflict of interest. The funders had no role in the design of the study; in the collection, analyses, or interpretation of data; in the writing of the manuscript; or in the decision to publish the results.

\section{References}

1. Demetriades, D.; Kimbrell, B.; Salim, A.; Velmahos, G.; Rhee, P.; Preston, C.; Gruzinski, G.; Chan, L. Trauma Deaths in a Mature Urban Trauma System: Is "Trimodal" Distribution a Valid Concept? J. Am. Coll. Surg. 2005, 201, 343-348. [CrossRef]

2. Sobrino, J.; Shafi, S. Timing and Causes of Death after Injuries. Bayl. Univ. Med. Cent. Proc. 2013, 26, 120-123. [CrossRef] [PubMed]

3. Gunst, M.; Ghaemmaghami, V.; Gruszecki, A.; Urban, J.; Frankel, H.; Shafi, S. Changing Epidemiology of Trauma Deaths Leads to a Bimodal Distribution. Bayl. Univ. Med. Cent. Proc. 2010, 23, 349-354. [CrossRef] [PubMed]

4. Ciesla, D.J.; Moore, E.E.; Johnson, J.L.; Burch, J.M.; Cothren, C.C.; Sauaia, A. A 12-Year Prospective Study of Postinjury Multiple Organ Failure: Has Anything Changed? Arch. Surg. 2005, 140, 432-438, discussion 438-40. [CrossRef]

5. Lord, J.M.; Midwinter, M.J.; Chen, Y.-F.; Belli, A.; Brohi, K.; Kovacs, E.J.; Koenderman, L.; Kubes, P.; Lilford, R.J. The Systemic Immune Response to Trauma: An Overview of Pathophysiology and Treatment. Lancet 2014, 384, 1455-1465. [CrossRef]

6. Lefering, R.; Paffrath, T.; Bouamra, O.; Coats, T.J.; Woodford, M.; Jenks, T.; Wafaisade, A.; Nienaber, U.; Lecky, F. Epidemiology of in-Hospital Trauma Deaths. Eur. J. Trauma Emerg. Surg. 2012, 38, 3-9. [CrossRef]

7. Levy, M.M.; Evans, L.E.; Rhodes, A. The Surviving Sepsis Campaign Bundle: 2018 Update. Crit. Care Med. 2018, 46, 997-1000. [CrossRef]

8. Guisasola, M.C.; Alonso, B.; Bravo, B.; Vaquero, J.; Chana, F. An Overview of Cytokines and Heat Shock Response in Polytraumatized Patients. Cell Stress Chaperones 2018, 23, 483-489. [CrossRef]

9. Burk, R.F.; Hill, K.E. Regulation of Selenium Metabolism and Transport. Annu. Rev. Nutr. 2015, 35, 109-134. [CrossRef]

10. Berger, M.M.; Reymond, M.J.; Shenkin, A.; Rey, F.; Wardle, C.; Cayeux, C.; Schindler, C.; Chioléro, R.L. Influence of Selenium Supplements on the Post-Traumatic Alterations of the Thyroid Axis: A Placebo-Controlled Trial. Intensive Care Med. 2001, 27, 91-100. [CrossRef]

11. Gärtner, R.; Gasnier, B.C.H.; Dietrich, J.W.; Krebs, B.; Angstwurm, M.W.A. Selenium Supplementation in Patients with Autoimmune Thyroiditis Decreases Thyroid Peroxidase Antibodies Concentrations. J. Clin. Endocrinol. Metab. 2002, 87, $1687-1691$. [CrossRef]

12. Huang, Z.; Rose, A.H.; Hoffmann, P.R. The Role of Selenium in Inflammation and Immunity: From Molecular Mechanisms to Therapeutic Opportunities. Antioxid. Redox Signal. 2012, 16, 705-743. [CrossRef] [PubMed]

13. Hollenbach, B.; Morgenthaler, N.G.; Struck, J.; Alonso, C.; Bergmann, A.; Köhrle, J.; Schomburg, L. New Assay for the Measurement of Selenoprotein P as a Sepsis Biomarker from Serum. J. Trace Elem. Med. Biol. 2008, 22, 24-32. [CrossRef]

14. Braunstein, M.; Kusmenkov, T.; Zuck, C.; Angstwurm, M.; Becker, N.-P.; Böcker, W.; Schomburg, L.; Bogner-Flatz, V. Selenium and Selenoprotein P Deficiency Correlates with Complications and Adverse Outcome After Major Trauma. Shock 2020, 53, 63-70. [CrossRef] [PubMed] 
15. Choi, S.B.; Jung, Y.T.; Lee, J.G. Association of Initial Low Serum Selenium Level with Infectious Complications and 30-Day Mortality in Multiple Trauma Patients. Nutrients 2019, 11, 1844. [CrossRef] [PubMed]

16. Jang, J.Y.; Shim, H.; Lee, S.H.; Lee, J.G. Serum Selenium and Zinc Levels in Critically Ill Surgical Patients. J. Crit. Care 2014, 29, 317.e5-317.e8. [CrossRef]

17. Angstwurm, M.W.A.; Engelmann, L.; Zimmermann, T.; Lehmann, C.; Spes, C.H.; Abel, P.; Strauss, R.; Meier-Hellmann, A.; Insel, R.; Radke, J.; et al. Selenium in Intensive Care (SIC): Results of a Prospective Randomized, Placebo-Controlled, Multiple-Center Study in Patients with Severe Systemic Inflammatory Response Syndrome, Sepsis, and Septic Shock. Crit. Care Med. 2007, 35 , 118-126. [CrossRef]

18. Klein, G.L.; Rodriguez, N.A.; Branski, L.K.; Herndon, D.N. Vitamin and Trace Element Homeostasis Following Severe Burn Injury. In Total Burn Care; WB Saunders: London, UK, 2012; pp. 321-324.

19. Kurmis, R.; Greenwood, J.; Aromataris, E. Trace Element Supplementation Following Severe Burn Injury: A Systematic Review and Meta-Analysis. J. Burn Care Res. 2016, 37, 143-159. [CrossRef]

20. Mertens, K.; Lowes, D.A.; Webster, N.R.; Talib, J.; Hall, L.; Davies, M.J.; Beattie, J.H.; Galley, H.F. Low Zinc and Selenium Concentrations in Sepsis Are Associated with Oxidative Damage and Inflammation. Br. J. Anaesth. 2015, 114, 990-999. [CrossRef]

21. McClave, S.A.; Taylor, B.E.; Martindale, R.G.; Warren, M.M.; Johnson, D.R.; Braunschweig, C.; McCarthy, M.S.; Davanos, E.; Rice, T.W.; Cresci, G.A.; et al. Guidelines for the Provision and Assessment of Nutrition Support Therapy in the Adult Critically Ill Patient: Society of Critical Care Medicine (SCCM) and American Society for Parenteral and Enteral Nutrition (A.s.p.e.n.). JPEN 2016, 40, 159-211. [CrossRef]

22. Higgins, J.P.T.; Thomas, J.; Chandler, J.; Cumpston, M.; Li, T.; Page, M.J.; Welch, V.A. Cochrane Handbook for Systematic Reviews of Interventions; John Wiley \& Sons: Hoboken, NJ, USA, 2019; ISBN 9781119536611.

23. Porter, J.M.; Ivatury, R.R.; Azimuddin, K.; Swami, R. Antioxidant Therapy in the Prevention of Organ Dysfunction Syndrome and Infectious Complications after Trauma: Early Results of a Prospective Randomized Study. Am. Surg. 1999, 65, 478-483.

24. Berger, M.M.; Soguel, L.; Shenkin, A.; Revelly, J.-P.; Pinget, C.; Baines, M.; Chioléro, R.L. Influence of Early Antioxidant Supplements on Clinical Evolution and Organ Function in Critically Ill Cardiac Surgery, Major Trauma, and Subarachnoid Hemorrhage Patients. Crit. Care 2008, 12, R101. [CrossRef]

25. Collier, B.R.; Giladi, A.; Dossett, L.A.; Dyer, L.; Fleming, S.B.; Cotton, B.A. Impact of High-Dose Antioxidants on Outcomes in Acutely Injured Patients. JPEN 2008, 32, 384-388. [CrossRef]

26. Giladi, A.M.; Dossett, L.A.; Fleming, S.B.; Abumrad, N.N.; Cotton, B.A. High-Dose Antioxidant Administration Is Associated with a Reduction in Post-Injury Complications in Critically Ill Trauma Patients. Injury 2011, 42, 78-82. [CrossRef] [PubMed]

27. van Zanten, A.R.H.; Sztark, F.; Kaisers, U.X.; Zielmann, S.; Felbinger, T.W.; Sablotzki, A.R.; De Waele, J.J.; Timsit, J.-F.; Honing, M.L.H.; Keh, D.; et al. High-Protein Enteral Nutrition Enriched with Immune-Modulating Nutrients vs. Standard High-Protein Enteral Nutrition and Nosocomial Infections in the ICU: A Randomized Clinical Trial. JAMA 2014, 312, 514-524. [CrossRef] [PubMed]

28. Soguel, L.; Chioléro, R.L.; Ruffieux, C.; Berger, M.M. Monitoring the Clinical Introduction of a Glutamine and Antioxidant Solution in Critically Ill Trauma and Burn Patients. Nutrition 2008, 24, 1123-1132. [CrossRef] [PubMed]

29. Bloos, F.; Trips, E.; Nierhaus, A.; Briegel, J.; Heyland, D.K.; Jaschinski, U.; Moerer, O.; Weyland, A.; Marx, G.; Gründling, M.; et al Effect of Sodium Selenite Administration and Procalcitonin-Guided Therapy on Mortality in Patients with Severe Sepsis or Septic Shock: A Randomized Clinical Trial. JAMA Intern. Med. 2016, 176, 1266-1276. [CrossRef]

30. Chelkeba, L.; Ahmadi, A.; Abdollahi, M.; Najafi, A.; Ghadimi, M.H.; Mosaed, R.; Mojtahedzadeh, M. The Effect of High-Dose Parenteral Sodium Selenite in Critically Ill Patients Following Sepsis: A Clinical and Mechanistic Study. Indian J. Crit. Care Med. 2017, 21, 287-293.

31. Bentzer, P.; Fjell, C.; Walley, K.R.; Boyd, J.; Russell, J.A. Plasma Cytokine Levels Predict Response to Corticosteroids in Septic Shock. Intensive Care Med. 2016, 42, 1970-1979. [CrossRef]

32. Brätter, P.; Negretti de Brätter, V.E. Influence of High Dietary Selenium Intake on the Thyroid Hormone Level in Human Serum. J. Trace Elem. Med. Biol. 1996, 10, 163-166. [CrossRef]

33. Wongdokmai, R.; Shantavasinkul, P.C.; Chanprasertyothin, S.; Panpunuan, P.; Matchariyakul, D.; Sritara, P.; Sirivarasai, J. The Involvement of Selenium in Type 2 Diabetes Development Related to Obesity and Low Grade Inflammation. Diabetes Metab. Syndr. Obes. 2021, 14, 1669-1680. [CrossRef]

34. Cabral, M.; Kuxhaus, O.; Eichelmann, F.; Kopp, J.F.; Alker, W.; Hackler, J.; Kipp, A.P.; Schwerdtle, T.; Haase, H.; Schomburg, L.; et al. Trace Element Profile and Incidence of Type 2 Diabetes, Cardiovascular Disease and Colorectal Cancer: Results from the EPIC-Potsdam Cohort Study. Eur. J. Nutr. 2021, 60, 3267-3278. [CrossRef]

35. Lin, J.; Shen, T. Association of Dietary and Serum Selenium Concentrations with Glucose Level and Risk of Diabetes Mellitus: A Cross Sectional Study of National Health and Nutrition Examination Survey, 1999-2006. J. Trace Elem. Med. Biol. 2021, 63, 126660. [CrossRef] [PubMed]

36. Moon, S.; Chung, H.S.; Yu, J.M.; Yoo, H.J.; Park, J.H.; Kim, D.S.; Park, Y.-K.; Yoon, S.N. Association between Serum Selenium Level and the Prevalence of Diabetes Mellitus in U.S. Population. J. Trace Elem. Med. Biol. 2019, 52, 83-88. [CrossRef] [PubMed]

37. Siddiqi, S.M.; Sun, C.; Wu, X.; Shah, I.; Mehmood, A. The Correlation between Dietary Selenium Intake and Type 2 Diabetes: A Cross-Sectional Population-Based Study on North Chinese Adults. Biomed. Res. Int. 2020, 2020, 8058463. [CrossRef] [PubMed] 
38. Stranges, S.; Rayman, M.P.; Winther, K.H.; Guallar, E.; Cold, S.; Pastor-Barriuso, R. Effect of Selenium Supplementation on Changes in HbA1c: Results from a Multiple-Dose, Randomized Controlled Trial. Diabetes Obes. Metab. 2019, 21, 541-549. [CrossRef]

39. Raygan, F.; Behnejad, M.; Ostadmohammadi, V. Selenium Supplementation Lowers Insulin Resistance and Markers of CardioMetabolic Risk in Patients with Congestive Heart Failure: A Randomised, Double-Blind. Br. J. Anaesth. 2018, 120, 33-40. [CrossRef]

40. Liu, A.; Xu, P.; Gong, C.; Zhu, Y.; Zhang, H.; Nie, W.; Zhou, X.; Liang, X.; Xu, Y.; Huang, C.; et al. High Serum Concentration of Selenium, but Not Calcium, Cobalt, Copper, Iron, and Magnesium, Increased the Risk of Both Hyperglycemia and Dyslipidemia in Adults: A Health Examination Center Based Cross-Sectional Study. J. Trace Elem. Med. Biol. 2020, 59, 126470. [CrossRef]

41. Huang, Y.-Q.; Shen, G.; Lo, K.; Huang, J.-Y.; Liu, L.; Chen, C.-L.; Yu, Y.-L.; Sun, S.; Zhang, B.; Feng, Y.-Q. Association of Circulating Selenium Concentration with Dyslipidemia: Results from the NHANES. J. Trace Elem. Med. Biol. 2020, 58, 126438. [CrossRef] 